\title{
РЕФЕРАТЫ.
}

\section{Обзорз алу프ско-гинегологической литературы:}

\author{
a) Р у с с к $О$ й.
}

221. А. А. Новицкій.-Объ оперативномъ лйченіи перегвбовъ матки назадъ съ пришиваніемъ къ переднему своду.(Проток. засъд. Имп. Кавказск. Мед. Общ., 2-го мая 1895 г., стр. 34).

Описано 2 случая. Въ шервомъ, у 27 льٔтней женщины, шодвижная магка пришита кь переднему своду по Mackenrodt'y. На третій день матка приняла прежнее положеніе. Во второмь случањ, у 29 льтней женщины, матка, менъе подвижная, припита къ переднему своду шо тому же способу, при чемъ во время операдіи она удерживалась въ данном' ей положеніи свинцовымъ сильно изогнутымъ бужомъ. Результать получился прекрасный.

Н. Какушкинг.

222. А. А. Новицвій.- Къ діагностик' межсвязочныхъ кисть яичника. - (Шроток. засььд. Имп. Кавказск. Мед. Общ., 2-го мая 1895 г., стр. 26).

У больной дл операціи была распознана фиброміома матки, вроспая въ широкую связку, однако при чревосњченіи обнаружилось, что это была киста съ тнойнымъ содержимымъ. Она была оперирована въ два пріема: сначала вшита въ рану, а заттмъ вскрыта и опорожнена. Шосль операпіи распознованіе колебалоск между кистой тирокой связки и между расширенной трубой. Стьнка кисты не была обсль্ъдована микроскопически, но удлиненіе полости матки, отсутствіе перехвата между маткой и опухолью и порядочная величина опухоли заставили автора признать здъсь кисту широкой связки.

H. Какуикинг. 